International Journal of Instruction e-ISSN: 1308-1470 • www.e-iji.net

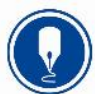

October $2019 \bullet$ Vol.12, No.4

p-ISSN: 1694-609X

$$
\text { pp. 443-458 }
$$

Received: 07/02/2019

Revision: 24/06/2019

Accepted: 29/06/2019

OnlineFirst:04/09/2019

\title{
Development of Living Values (Honesty) Assessment Instrument in Learning Process
}

\section{Siti Sarah}

Science Education, Yogyakarta State University, Sains Al Quran University, Physics Education, Indonesia, st.sarah44@ gmail.com

\section{Zuhdan Kun Prasetyo}

Yogyakarta State University, Master of Science Education, Indonesia, zuhdan@uny.ac.id

\section{Insih Wilujeng}

Yogyakarta State University, Master of Science Education, Indonesia, insih@uny.ac.id

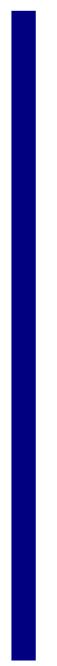

The cheating among students shows a low value of honesty. A learning process in high school loaded with living values, namely honesty. This study aims to produce instruments to measure honesty in the learning process that is valid and reliable. The research used for research and development methods with 8 steps, namely (1) determining instrument specifications, (2) compiling, (3) choosing a measurement scale, (4) scoring, (5) examining, (6) limited experiment, (7) analyzing, and (8) concluding. The first trial involved 1167 parents of high school students in x class. A second trial involved 1261 parents of high school students on xi and xii class. Respondents lived in Wonosobo Regency, Indonesia. The research instruments included a questionnaire, observation, and interview instruction sheets. Data were analysed by expert judgment and explanatory factor analysis. Research produces valid and reliable instruments to measure honesty. A questionnaire with 4 items have Alpha's Cronbach coefficient 0.840. The observation consisted of 3 items with very good criteria. The interview guide has fulfilled the content validity after being corrected based on expert advice. The implication of the study is the students' honesty can be measure early so as not to develop into dishonest behaviour and lead to criminal acts.

Keywords: honesty, assessment, instrument, learning process, living values

\section{INTRODUCTION}

The people of Indonesia highly uphold the noble values of the nation such as honesty, politeness, togetherness, religion, and others which are all listed in the state foundation, 
namely Pancasila. The noble values have taken root in the attitudes and behaviors of life forming character (Zuchdi, 2012). However, along with the development of the era the character is increasingly fading. Indonesian people hope education can create graduates that benefit the community. It can be fulfilled if graduates have good character (Mardapi, 2017). Therefore, starting in 2013 until now the Indonesian National Education system seeks to make Indonesian people not only have intelligence, but also good spiritual, personal, and self-control characters (Hidayati, et al., 2018). This step is realized by inclusion the achievement of characters in the curriculum (Regulation of the Minister of National Education-Kemendiknas, 2010).

The character is a moral quality and is a consideration for someone in making decisions, acting, and behaving that are relatively fixed (Mardapi, 2017). The character is not a variable that can be achieved quickly. It takes a long time to reach it. Characters are formed by values, autonomy, and determination and loyalty (Zuchdi et al., 2013). Pancasila, the basis of the Indonesian state explains the character of the Indonesian nation which turns out to be in line with the achievement of living values (Komalasari \& Saripudin, 2018). Living values are the basic values of character building. It is easy to be internalized and implemented. Komalasari (2012) \& Wening (2012) said that living values contributed $26 \%$ to the formation of national character. Living values through habitual activities in school can improve student character (Komalasari et al., 2014). Tillman (2004) fosters living values by encouraging students to see their actions in others and how they can make a difference.

Living values are closely related to culture. Culture is used in various contexts which means many different things and generally refers to habit, practices, language, values that grow in society (Daskon, 2015). Komalasari (2012) shows 13 living values that can be developed in Indonesia namely religious, honesty, tolerance, ethical behavior, discipline, working hard, creative, independent, democratic, loving the country, respecting achievement, working together, and responsible. Among the 13 living values, honesty is the most urgent living values for all elements of the nation.

Dishonesty practices such as plagiarism and cheating behavior are prevalent in society (Mazar et al., 2008). Lickona (2013) states that one sign of the nation's destruction is to cultivate dishonesty. Honesty is not the only attitude, but dignity, self-esteem, one's identity and national identity (Muhasim, 2017).

Plagiarism practices occur in almost all countries in the world such as America, Bangladesh, India, Pakistan, Malaysia, Africa, Norway, Kenya, Iran, and America (Moten, 2014). Bunn, Caudill, and Gropper (1992) shows that the majority of students admits to cheating/plagiarism while taking college. Cheating among students was no less alarming. The results of the Josephson Institute Center for Youth survey of 23,000 public and private high school students found that $51 \%$ of students cheated during the year-end test. The survey also found that $74 \%$ of students copied the homework of other students (Ehrlich \& Fu, 2013).

Based on the information, dishonesty has existed from ancient times until now. Rules for perpetrators of dishonesty already exist. The punishment for the perpetrator of 
dishonesty has been carried out. However, the practice of dishonesty still continues. Honesty is an attitude or behavior that will develop into a habit. It takes a long time (Shalvi et al., 2012). The practices of dishonesty start from simple attitudes and behavior. It should be detected as early as possible so as not to develop. The lie detector (polygraph) is only used to detect the lies of perpetrators of crime in the legal sphere. Novodvorsky (1993) developed an instrument for measuring attitudes (honesty) in science at the high school level using questionnaires filled with students. The limited detection of dishonesty is feared to be less able to reveal someone's honesty appropriately. Therefore, it is necessary to assess honesty using a valid assessment instrument (Mardapi, 2017). LaForgia (1988) states that "researchers need to provide reliable and valid and unsustainable evaluation tools as they did in the past by developing instruments that will hardly meet simple criteria". This study aims to develop instruments to measure honesty through the learning process. It takes learning processes from the side of physics learning because it is at the core. The process includes observation, demonstration, and experiment (Klieger \& Sherman, 2015; Ogunleye \& Babajide, 2011). When making observations, careful and honest behavior is needed to produce significant data (Scheider, 1980). The honesty assessment instrument is expected to be a reference for everyone, especially teachers, to check the honesty of their students in the school environment and people in the family environment. Thus, measurement of honesty will get complete information.

\section{METHOD}

\section{Type of Research}

This study is a research and development ( $R$ \& D) model by Mardapi (2017) design in 10 steps. The study only takes eight stages because the process of character formation takes a long time (Mardapi, 2017; Zuchdi, et al., 2013). The eight steps were (1) determining instrument specifications, (2) compiling, (3) choosing a measurement scale, (4) making scoring, (5) examining, (6) doing a limited experiment, (7) analyzing, and (8) concluding.

Instrument specifications include setting goals and framework. The goals include data types and instruments. The framework was formed by constructing instruments based on conceptual definitions. It took from theories. Conceptual definitions developed into operational definitions and then developed into many indicators. It was used as guidelines to make items. The instrument equips with a scale of measurement and score. It was reviewed by experts to find out the quality of the items. After being valid, it was tested to the respondent to fulfill the content validity by a statistical test. The results used to analyze and produce a final instrument. Limited experiments are only conducted on questionnaires. This is not done on the observation sheet and interview guidelines because it is constrained by bureaucracy and takes a long time.

\section{Respondents}

Wonosobo is regency in Central Java, Indonesia with a high percentage of poor people (20.32) and poverty depth index (1.10) in 2013-2017. On education, the net enrollment 
rate of high school students is low. This criterion comes from a comparison of data from other regencies in Central Java (BPS-Statistics of Wonosobo Regency, 2018).

There are sixteen high schools in Wonosobo. They are eleven public high schools and five private high schools. In this research, the school was chosen randomly by drawing. They are seven public high schools and two private high schools. On the first trial, the respondents were the parents of students who learn physics in the school of $\mathrm{x}$ class. On the second trial, parents of a student who learn physics in the school of xi and xii class were chosen to be respondents. Physics learning has chosen because of the characteristics of the learning process.

\section{Data Collection Instruments}

Data collected through a questionnaire, observation sheets, and an interview. The questionnaire consists of eight items. It contains questions about students 'honesty based on the parents' observations at home. The observation sheet measures students' honesty while doing the learning process. Observations were carried out by two observers. The interview sheet is semi-closed style. The interview was aimed at many students. Figure 1 clarifies the type of instrument in this study.

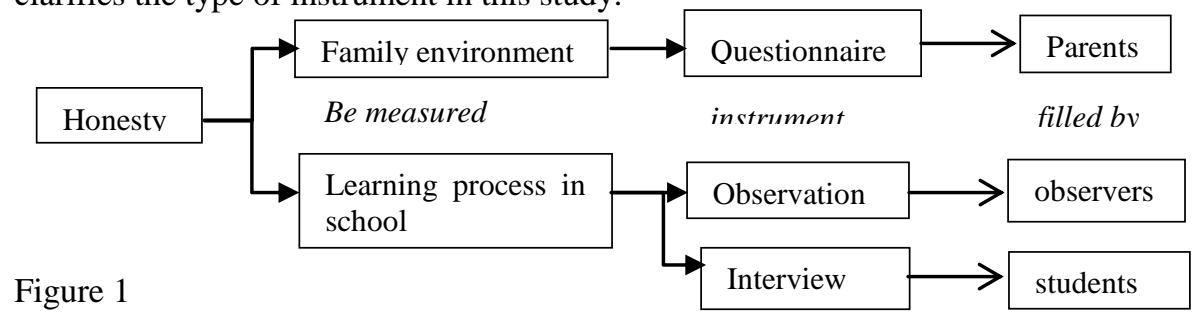

Diagram of How to Measure Honesty

\section{Data Analysis}

Data analyzed through judgment by six experts. They are three universities, academics and three physics teachers. The academics are physics learning, linguists, and measurement experts. The physics teachers came from public high school (two persons) and a private high school (one person). They assess the instrument, including content, language, and construction. The measurement results are converted to four scale values by reference to Table 1 . Instruments fulfill the content validity by the expert judgment if the results of the assessment indicate the criteria of "very good" and "good '

Table 1

Conversion of Measurement Results

\begin{tabular}{lll}
\hline No & Interval score & Category \\
\hline 1 & $x \geq \bar{x}+1 . S B x$ & Very good \\
2 & $\bar{x}+1 . S B x>x \geq \bar{x}$ & Good \\
3 & $\bar{x}>x \geq \bar{x}-1 . S B x$ & Not good \\
4 & $x<\bar{x}-1 . S B x$ & Very bad \\
\hline
\end{tabular}

Description (Mardapi, 2008): 
$\bar{x}=$ mean ideal $=1 / 2$ (ideal highest score + ideal lowest score)

$S B x=$ standard deviation ideal score $\left(\mathrm{SB}_{\mathrm{i}}\right)=1 / 6$ (ideal highest score - ideal lowest score)

$x=$ score

Especially in the questionnaire data analysis was continued by explanatory factor analysis (EFA). EFA aims to find out the factors that construct honesty while proving the construct validity of the questionnaire. It was analyzed by SPSS version 25.00. Chisquare at the Barlette Test showed the adequacy of the sample. The sample was sufficient when the significance value is less than 0.01 . This data are reinforced by KMO MSA when values above 0.50 (Hair, et al., 2010). Questionnaire reliability knows by Cronbach's Alpha coefficient.

\section{FINDINGS}

\section{Determining Instrument Specifications (Step 1)}

Living values are the basis of character building. This value is easy to internalize and implement. There are 13 living values can be developed in Indonesia (Komalasari, 2012). One of them is honesty. Honesty is telling the truth. It means no contradiction in thoughts, words, or actions. Honesty makes integrity in life. There is a close relationship between honesty and friendship. Honest people know that everyone is interconnected. Be honest with yourself and in the face of assignments, will gain trust from and inspire others (Tillman, 2004). Komalasari (2012) defines more specifically. Honesty is a behavior that makes someone trusted by words, actions, and work. Mazar et al. (2008) said that dishonesty people are quite profitable but are cheating themselves.

Honesty is the attitude and behavior of a person to make himself always trustworthy in words and deeds. Indicators of honesty include: (1) not lying, (2) not cheating, (3) maintaining the trust of others, and (4) writing actual experimental data.

A character is part of the affective domain (Mardapi, 2017). That is, living values are also part of the affective aspect. Affective domain includes 5 stages, namely receiving, responding, valuing, organization, and characterization. Receiving means students have desires. Responding means that students not only have desires but also react. Valuing means that students have consistent and stable behavior as a result of learning. Learning outcomes at the organizational stage are in the form of value conceptualization. In the realm of characterization, students have a value system that controls behavior until particular time to form a lifestyle (Krathwohl et al., 1964). Methods of measuring affective domains include observation and self-reporting (Andersen, 1981). Assessment in the affective domain requires quantitative or qualitative data. Quantitative data are obtained through measurements. The results are in the form of numbers. Qualitative data are obtained through non-test instruments, such as observation guidelines and questionnaires. Based on theoretical studies, this study developed 3 instruments, namely observation sheet, questionnaire sheet, and interview guideline sheet. Observation sheet measured students' honesty in the learning process. The questionnaire sheet is filled by student' parents. The interview guideline contains a series of questions about student honesty. Interviews are conducted with students. 
Table 2

The Framework of Honesty Instruments in the Learning Process

\begin{tabular}{cll}
\hline No & Indicators & Instruments \\
\hline 1 & not lying & $\begin{array}{l}\text { Questionnaire sheet } \\
\text { Interview sheet }\end{array}$ \\
\hline 2 & not cheating & $\begin{array}{l}\text { Questionnaire sheet } \\
\text { Interview sheet } \\
\text { Observation sheet }\end{array}$ \\
\hline 3 & maintaining the trust of others & $\begin{array}{l}\text { Questionnaire sheet } \\
\text { Interview sheet }\end{array}$ \\
\hline 4 & writing experiment data & Observation sheet \\
\hline
\end{tabular}

\section{Compiling (Step 2)}

Instrument was making by the reference framework in Table 3. An honesty questionnaire consists of 8 items in the form of positive and negative statements and spread randomly, so that the respondent does not guess. The observation sheet and interview guideline sheet are each composed of 3 items.

Table 3

Items on the Questionnaire

\begin{tabular}{lll}
\hline \multicolumn{1}{c}{ Indicators } & Item indicators & Item number \\
\hline Not lying & Speaking based on facts in the field & 1 \\
& No Speaking based on the fact & 4 \\
\hline Not cheating & Has someone else done the work & 2 \\
& Working on tasks by their self & 5 \\
\hline Maintaining the & Returning other people's object by properly and cleanly & 6 \\
trust of other & No returning other people's object & 3 \\
& Ask permission before using other people's items & 7 \\
& No permission when using other people's items & 8 \\
\hline
\end{tabular}

Table 4

Items on the Observation Sheet

\begin{tabular}{lll}
\hline \multicolumn{1}{c}{ Indicators } & Item indicators & Item number \\
\hline Not cheating & No copying data from other people or groups & 1 \\
\hline Maintaining the trust of other & Working on problems based on their abilities & 2 \\
\hline Writing data from experiment & $\begin{array}{l}\text { Writing data according to experimental } \\
\text { results }\end{array}$ & 3 \\
\hline
\end{tabular}

Table 5

Items on the Interview Guideline Sheet

\begin{tabular}{lll}
\hline \multicolumn{1}{c}{ Indicators } & Questions item & Item number \\
\hline Not lying & $\begin{array}{l}\text { Are there any dishonest behaviors that you } \\
\text { have done? If yes, give an example. }\end{array}$ & 1 \\
\hline Not cheating & $\begin{array}{l}\text { Are there cheating behaviors that you have } \\
\text { ever done? If yes, what kind of cheating } \\
\text { behavior have you done? }\end{array}$ & 2 \\
\hline Maintaining the trust of other & How do you maintain the trust of others? & 3 \\
\hline
\end{tabular}




\section{Choosing a Measurement Scale (Step 3) and Scoring (Step 4)}

Questionnaire items are arranged using a Likert scale in the range of 1 to 4 , namely $1=$ never, $2=$ rarely, $3=$ often, $4=$ always. Never are means never doing. Rarely means ever doing, but with a long-time span, such as 1 or 2 times in 1 month. Often means doing something several times, which is 1 to 2 times a week. It always means doing things continuously. That is, the behavior has become a habit. The observation sheet is made using a rubric with 4 scales. Score 1 if there is no one indicator fulfilled. Score 2, if there is 1 indicator is fulfilled. Score 3, if there are 2 indicators are fulfilled. Score 4, if there are 3 indicators are fulfilled.

\section{Examining (Step 5)}

The examining instrument aims to find out the quality of questions or statements based on indicators by expert judgment.

Table 6

Results of a Questionnaire Sheet Review by Expert Judgment

\begin{tabular}{lllll}
\hline Validators & Aspect & Average score & Maximum Score & Category \\
\hline \multirow{3}{*}{ Universities academics } & Content & 4.33 & 5 & Very good \\
& Language & 24.67 & 25 & Very good \\
& Construction & 14.67 & 15 & Very good \\
\hline \multirow{3}{*}{ Physics teachers } & Content & 4.00 & 5 & Very good \\
& Language & 21.50 & 25 & Very good \\
& Constructions & 13.23 & 15 & Very good \\
\hline
\end{tabular}

Table 6 shows that universities academics stated that the questionnaire was in the criteria of "very good" in content, language, and construction aspects. The physics teachers gave the same assessment with the university academics about the questionnaire. That is, the questionnaire sheet has fulfilled content validity.

Table 7

Results of an Observation Sheet Review by Expert Judgment

\begin{tabular}{lllll}
\hline Validators & Aspect & Average score & Maximum score & Category \\
\hline \multirow{3}{*}{ Universities academics } & Content & 4.33 & 5 & Very good \\
& Language & 14 & 15 & Very good \\
& Construction & 13.33 & 15 & Very good \\
\hline \multirow{3}{*}{ Physics teacher } & Content & 4.5 & 5 & Very good \\
& Language & 13.5 & 15 & Very good \\
& Constructions & 15 & 15 & Very good \\
\hline
\end{tabular}

Table 7 shows that universities academics and physics teacher consider the observation sheet to be in the "very good" category in content, language, and construction aspects. That is, the observation sheet has fulfilled content validity. 
Table 8

Results of Interview Guideline Validation by Expert Judgment

\begin{tabular}{lllll}
\hline Validators & Aspect & Average score & Maximum score & Category \\
\hline \multirow{3}{*}{ Universities academics } & Content & 2.67 & 5 & Not good \\
& Language & 15 & 15 & Very good \\
& Construction & 5 & 5 & Very good \\
\hline \multirow{3}{*}{ Physics teachers } & Content & 4.5 & 5 & Very good \\
& Language & 13.5 & 15 & Very good \\
& Constructions & 4.5 & 5 & Very good \\
\hline
\end{tabular}

Table 8 shows that all experts gave a "very good" assessment of all aspects of the interview guide except the contents of universities academics by "not good" criteria. According to universities academics, the questions are not detailed enough to gather information about students' honesty. Therefore, questions are corrected so that more detailed information about student honesty.

\section{Doing Limited Experiment (Step 6)}

The limited experiment was only carried out on questionnaires filled out by parents. Questionnaires were distributed to high school in the Wonosobo District by physics teachers' helping. A total of 9 high schools were involved in this study. They are 7 public high schools and 2 private high schools. The questionnaire has spread for one week. After one week a questionnaire was taken back. There are 1240 questionnaires distributed, but 1184 were returned. After going through the sorting stage, 1167 questionnaires fulfilled the requirements for analysis. Sort was done because some questionnaires contain the same answer for all items. This indicates the respondent answered the questionnaire carelessly. Some respondents fill only a few items, but the others are left blank.

\section{Analyzing Instruments (Step 7)}

The adequacy of the sample shows the Chi-square value in the Bartlett test of 1013.420 with degrees of freedom 28 and p-values less than 0.01 . That is, the sample size of 1167 used is sufficient. It is corroborated by the Kaiser Meyer Olkin measure of adequacy sampling (KMO) of 0.721 greater than 0.5 .

The analysis was continued to find out the forming factors of honesty. The anti-image correlation (AIC) in Table 9 shows the variables that are feasible to use in carrying out factor analysis. It can be seen from the value of a Measure of Sampling Adequacy (MSA) by "a" code. MSA values above 0.50 indicate items are feasible to use factor analysis (Hair, 2010). 
Table 9

Anti-Image Matrices

\begin{tabular}{lccccccccc}
\hline & & Item2 & Item3 & Item4 & \multicolumn{1}{c}{ Item8 } & \multicolumn{1}{l}{ Item5 } & \multicolumn{1}{l}{ Item6 } & \multicolumn{1}{l}{ Item7 } & \multicolumn{1}{l}{ Item1 } \\
\hline Anti-image & Item2 & $0.750^{\mathrm{a}}$ & -0.195 & -0.135 & -0.035 & -0.059 & -0.048 & -0.020 & -0.031 \\
Correlation & Item3 & -0.195 & $0.779^{\mathrm{a}}$ & -0.058 & -0.069 & -0.009 & -0.180 & -0.100 & -0.016 \\
& Item4 & -0.135 & -0.058 & $0.769^{\mathrm{a}}$ & -0.081 & -0.018 & -0.078 & 0.011 & -0.110 \\
& Item8 & -0.035 & -0.069 & -0.081 & $0.670^{\mathrm{a}}$ & 0.017 & -0.015 & -0.412 & 0.004 \\
& Item5 & -0.059 & -0.009 & -0.018 & 0.017 & $0.758^{\mathrm{a}}$ & -0.112 & -0.051 & -0.145 \\
& Item6 & -0.048 & -0.180 & -0.078 & -0.015 & -0.112 & $0.746^{\mathrm{a}}$ & -0.296 & -0.129 \\
& Item7 & -0.020 & -0.100 & 0.011 & -0.412 & -0.051 & -0.296 & $0.668^{\mathrm{a}}$ & -0.054 \\
& Item1 & -0.031 & -0.016 & -0.110 & 0.004 & -0.145 & -0.129 & -0.054 & $0.761^{\mathrm{a}}$ \\
\hline
\end{tabular}

The extraction factor was carried out using the PCA method followed by factor rotation using the varimax method. Table 10 shows the value of communalities at item 3 , item 4 , and item6 less than 0.50 . Variables should generally have commonalities of greater than 0.50 to be retained in the analysis. Re-specification of factor analysis can include such option as (1) deleting a variable, (2) changing rotation methods, or (3) increasing or decreasing the number of factors (Hair, et. al. 2010). Therefore, an EFA test is carried out again by issuing items with the value of communalities below 0.50. EFA is carried out several times until all the prerequisites are significance.

Tabel 10

Communalities

\begin{tabular}{lllllllll}
\hline Item & Item2 & Item3 & Item4 & Item8 & Item5 & Item6 & Item7 & Item1 \\
\hline Initial & 1.000 & 1.000 & 1.000 & 1.000 & 1.000 & 1.000 & 1.000 & 1.000 \\
Extraction & .609 & .456 & .427 & .631 & .581 & .496 & .721 & .541 \\
\hline
\end{tabular}

The last EFA that fulfilled significant aspects were item2, item5, item7, and item8. All MSA values and the value of communalities above 0.50. Total Variance Explained, component matrix and Component Transformation Matrix show that two factors formed honesty. The questionnaire reliability is 0.448 . The generally agreed upon lower limit for Cronbach's alpha is 0.70 (Robinson, et. al., 1991). Therefore, efforts need to be made to produce a reliable questionnaire.

The two factors can affect the reliability, namely (1) the length of the test and the quality of the instrument, (2) the condition during data collection (Retnawati, 2017). This study seeks to fix the quality of questionnaire items to improve reliability. After that, the instrument was tested. A total of 1261 questionnaires that have been filled by parents of students who carry out physics learning were collected.

The EFA results show the Chi-square value in the Bartlett test of 4059.11 with degrees of freedom 28 and p-less than 0.01 values. The KMO is 0.902 greater than 0.5. All MSA values above 0.50 . All communalities values are above 0.50 except item $4(0.459)$ item 1 $(0.371)$, and item5 (0.154). EFA is done again with previously issued three items that have communalities below 0.50 so that the remaining five items.

The Chi-square value in the Bartlett test of 3048,892 with degrees of freedom 10 and pvalues is less than 0.01. The KMO and Bartlett's Test value is 0.856. All MSA values and commonalities are above 0.50. The total Cronbach's Alpha was 0.769 . 
Nevertheless, the value of Cronbach's Alpha if Item Deleted on item6 is more than the total of Cronbach's Alpha (0.813). Therefore, item6 was dropped.

The EFA process is repeated again with previously issued item4, item1, item5, and item6. The Chi-square value in the Bartlett test is 1944.106 with degrees of freedom 6 and p-less than 0.01 values. The KMO is 0.816. All MSA and communalities values above 0.50 (Table 11 and Table 12).

Table 11

Anti-Image Matrices

\begin{tabular}{llrrrr}
\hline & & \multicolumn{1}{c}{ Item2 } & \multicolumn{1}{c}{ Item3 } & \multicolumn{1}{c}{ Item7 } & \multicolumn{1}{c}{ Item8 } \\
\hline Anti-image Correlation & Item2 & $.826^{\mathrm{a}}$ & -.236 & -.329 & -.187 \\
& Item3 & -.236 & $.808^{\mathrm{a}}$ & -.333 & -.273 \\
& Item7 & -.329 & -.333 & $.794^{\mathrm{a}}$ & -.234 \\
& Item8 & -.187 & -.273 & -.234 & $.843^{\mathrm{a}}$ \\
\hline
\end{tabular}

Table12

Communalities

\begin{tabular}{lllll}
\hline Item & Item2 & Item3 & Item7 & Item8 \\
\hline Initial & 1.000 & 1.000 & 1.000 & 1.000 \\
Extraction & .661 & .699 & .718 & .630 \\
\hline
\end{tabular}

Table 13 shows that one factor formed honesty. Only the factors having eigenvalues greater than 1 are considered significant (Hair, 2010). It reinforced by Table 14 and Figure 2 that there is only one factor forming the honesty variable which covers item2, item3, item7, and item8. The value of the loading factor above 0.50 is generally considered necessary for practical significance (Hair, 2010). The results of factor analysis crosscheck with the framework. It has consulted with experts to produce a variable forming factor honesty that fixes, namely maintaining the trust of other by not cheating.

Table 13

Total Variance Explained

\begin{tabular}{lrrrrrr}
\hline & \multicolumn{3}{c}{ Initial Eigenvalues } & \multicolumn{3}{c}{ Extraction Sums of Squared Loadings } \\
\cline { 2 - 7 } Component & Total & \% of Variance & Cumulative \% & Total & \% of Variance & Cumulative \% \\
\hline 1 & 2.707 & 67.673 & 67.673 & 2.707 & 67.673 & 67.673 \\
2 & .495 & 12.373 & 80.046 & & & \\
3 & .426 & 10.648 & 90.695 & & & \\
4 & .372 & 9.305 & 100.000 & & & \\
\hline
\end{tabular}

Table 14

Component Matrix

\begin{tabular}{lr} 
& \multicolumn{1}{c}{ Component } \\
\cline { 2 - 2 } & \multicolumn{1}{c}{1} \\
\hline Item2 & .813 \\
Item3 & .836 \\
Item7 & .847 \\
Item8 & .794 \\
\hline
\end{tabular}




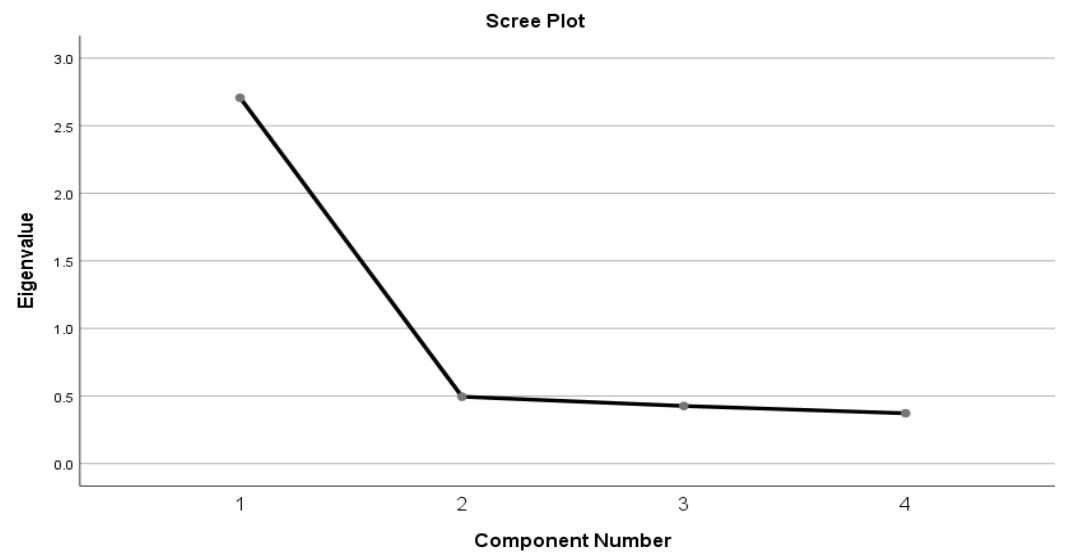

Figure 2

Scree Plot Factor of Honesty

The questionnaire reliability is 0.840 (Table 15). The reliability distribution of each item is in Table 16. All items have Corrected Item-Total Correlation above 0.30. Rules of thumb suggest that the item-total correlation exceed 0.30 (Robinson, et. al., 1991). All the Cronbach's Alpha if item deleted is less than the total of Cronbach's Alpha (Table 16). Thus, the honesty questionnaire has fulfilled the reliability aspects. It was sufficient to measure honesty in the field.

Table 15

Questionnaire Reliability

\begin{tabular}{ll}
\hline Cronbach's Alpha & N of Items \\
\hline 0.840 & 4 \\
\hline
\end{tabular}

Table 16

Reliability of questionnaire items

\begin{tabular}{lllll}
\hline & $\begin{array}{l}\text { Scale Mean if } \\
\text { Item Deleted }\end{array}$ & $\begin{array}{l}\text { Scale Variance if } \\
\text { Item Deleted }\end{array}$ & $\begin{array}{l}\text { Corrected Item- } \\
\text { Total Correlation }\end{array}$ & $\begin{array}{l}\text { Cronbach's Alpha } \\
\text { if Item Deleted }\end{array}$ \\
\hline Item2 & 10.2989 & 4.822 & 0.659 & 0.804 \\
Item3 & 10.3545 & 4.628 & 0.692 & 0.789 \\
Item7 & 10.1932 & 4.643 & 0.708 & 0.782 \\
Item8 & 10.3092 & 4.756 & 0.635 & 0.815 \\
\hline
\end{tabular}

\section{Concluding (Step 8)}

Based on the results of expert judgment and EFA, a valid and reliable instrument is established to measure honesty through the learning process. The instruments include a questionnaire, observation sheet, and interview guideline sheet. The questionnaire consists of 4 items (Table 17). It formed from maintaining the trust of others by not cheating. Alpha Cronbach was 0.840 . The observation sheet and interview guidelines consist of 3 items. The observation sheet was formed from not cheating and writing down real trial data. Interview guidelines were formed from not lying, not cheating, and maintaining the trust of others. 
Table 17

The Final Questionnaires

\begin{tabular}{cl}
\hline No & \multicolumn{1}{c}{ Statement } \\
\hline 1 & My child told someone else to do his job. \\
2 & My child borrows other people's items but does not return. \\
3 & My child asks for permission when he/she will use other people's items. \\
4 & My child did not ask permission first when he/she wanted to use other people's items. \\
\hline
\end{tabular}

\section{DISCUSSION}

The purpose of this study is to produce an instrument to assess honesty that is valid and reliable. Some honesty theories are used to compile indicators. These indicators include not lying, not cheating, maintaining the trust of others, and writing down real trial data. The indicator is used as the basis for determining instruments, including questionnaires, observation sheets, and interview guidelines.

The indicators reflected in the questionnaire with eight items, interview guideline and observation with three items. All instruments are validated in terms of content by experts from the university academics and physics teacher. Instruments fulfill content validation if the results of expert judgment are good criteria. The interview sheet is an instrument that has undergone the most changes based on expert advice, especially from university academics. These changes have found in the question content. The expert recommends that questions are sharper in exploring student honesty.

The questionnaire also tested to determine to construct validity and reliability. The limited experiment was the most difficult stages. It has required more time than the specified time allocation. The majority of the students forgot to return the questionnaire. Some students rent boarding rooms, so they rarely met the parents. Some students also lived separately with their parents for many years because of work outside the island and even abroad. The questionnaire was filled by the grandparents, uncle, or aunt.

EFA was conducted to determine the construct validity and Cronbach Alpha showing questionnaire reliability. In this study, EFA was carried out several times to produce significant data. The first EFA analyzed eight items from 1167 respondents' data. As a result, the value of KMO is 0.721 . MSA value is above 0.50 for all items. However, not all commonalities values fulfill significance because they are below 0.50 . These items are item3, item4, and item6. Therefore, the next EFA was carried out by previously issuing the three items. EFA stopped when significant results have been obtained. Significant EFA results are generated from item2, item8, item5, and item7. KMO is 0.541. All MSA values and commonalities are above 0.50 . The four items fulfill construct validity. However, reliability is only 0.448 . So the instrument is not reliable. Questionnaires with 8 items were repaired to have better quality. Here's an example. Item3

My child does not return other people's items that he borrowed. (Before)

My child borrows other people's items but does not return. (After)

Item6

My child returns other borrowed goods in good condition and is clean. (Before) 
My child returned the borrowed goods in good condition and clean. (After)

A total of 1261 respondents filled out the questionnaire. As a result, KMO is 0.902 and all items have MSA values above 0.50. However, item4, item1, and item5 have communality below 0.50 . Thus, EFA is carried out on the remaining 5 items. The result is KMO of 0.856 . All MSA and communality values are above 0.50 . Thus, five items fulfill the construct validation aspect and can be used to find out the honesty forming factors. The reliability of the five items is 0.769. It is reliable, but the value of Cronbach's Alpha Deleted Item on item6 is more than the total of Cronbach's Alpha (0.813). Therefore, item 6 was dropped. EFA is done again on four items that fulfill, namely item2, item3, item7, and item8.

As a result, KMO is 0.816 . All items have MSA and communality values above 0.50 . Thus, four items fulfilled the construct validation aspect and can be used to find out the honesty forming factors. The questionnaire reliability is 0.840 . All value of Cronbach's Alpha if Item Deleted not more than a total of Cronbach's Alpha. Thus, the four items meet the standards as questionnaire items to measure honesty.

The honesty indicators of the questionnaire in the framework and EFA results turned out differently. Based on EFA, not laying is not a factor forming honesty. Theoretically, 'not laying' is the main indicator of honesty (Tillman, 2004; Komalasari, 2012). The EFA results show that honesty is formed by the factor of maintaining the trust of others through not cheating.

Judging from the characteristics of respondents, they are generally not parents of students. Students generally come from families with low economic levels. Therefore, parents are forced to work outside the city and even abroad. Not even a few parents of students are divorced. Students live with grandparents, even grandmothers, or other families. Looking at the conditions, it is possible for respondents to be less careful in assessing student honesty. So, it is necessary for verifying by interviewing.

DePaulo, et.al (1996) examined lying behavior in a community. Some people consider lying as a process of everyday social interaction. They do not consider lies to be serious problems. So, they are not worried about getting caught up in the law. Lies in daily intimacy only result in relationships becoming less intimate than relationships without lies. Thus, it only affects the ethics of getting along. If so, the discussion of lying will lead to culture. That certainly requires further thought and in-depth research.

The development of an honest assessment instrument in the field of science has been carried out by Novodvorsky (1993). Apart from some of the differences, this research was necessary to be done because times have changed. The living value determinants have increased. "Researchers need to provide reliable and valid evaluation tools that are not sustainable as they did in the past by developing instruments that will hardly meet the simple criteria (LaForgia, 1988: 407).

This instrument was expected to be used as a reference to measure the honesty, especially students in the process of learning at school. The condition of students in the 
family also needs attention. It aims to ensure that parents' assessment of students is not biased. Hopefully, the practice of dishonesty detected as early as possible.

Further research, researchers want to develop honesty instruments through a learning process in a comprehensive manner that covers the school, family and community environment. Communities in this context are people around the place where students live, such as neighbors. The participation of the community to assess the students' honesty is very important. The full-day school phenomenon causes students to learn honesty from family and school. As a result, students lack the provision to survive in a pluralistic society. Even though, education is expected to prepare students to live in society. Some experts also recommended it. Honesty measurement instruments will be able to assess honesty comprehensively.

\section{LIMITATION}

The contents of the questionnaire were not checked by interviewing the parents of students. It is necessary for verifying. For researchers who want to use this instrument, it is recommended to conduct interviews with students' parents as a means of crossing the questionnaire data.

\section{CONCLUSION}

The valid and reliable honesty assessment instruments were produced, namely questionnaires, observation sheets, and interview sheet. All instruments fulfilled the content validity based on expert judgment assessment. EFA shows that the questionnaire fulfilled the construct validity. It formed by maintaining the trust of others by not cheating and consisted of four items. The reliability has fulfilled with a coefficient of 0.840 .

\section{SUGGESTION}

The results of this study need to be followed up with data collection in the field and dissemination. Then, ten steps to developing an honesty instrument are fulfilled.

\section{ACKNOWLEDGMENT}

The authors would like to thank the Ministry of Technology, Research, Higher Educations of the Republic of Indonesia (DIKTI) for funding this project. Thanks to LP3M Sains Al Quran University for all support and attention.

\section{REFERENCES}

Andersen, L. W. (1981). Assessing affective characteristic in the school. Boston: Allyn and Bacon.

BPS-Statistics of Wonosobo Regency. (2018). Wonosobo regency in figures. Wonosobo: BPS-Statistics of Wonosobo Regency.

Bunn, D. N., Caudill, S. B., \& Gropper, D. M. (1992) Crime in the classroom: An economic analysis of undergraduate student cheating behavior. The Journal of Economic Education, 23(3), 197-207. doi: 10.2307/1183222. 
Daskon, C. D. (2015). Significance of cultural values in securing asset portfolios of rural communities. Sri Lanka Journal of Social Sciences, 38(1), 31-50. doi: 10.4038/sljss.v38i1.7384.

DePaulo, B. M., Kashy, D. A., Kirkendol, S. E., Wyer, M. M., \& Epstein, J. A. (1996). Lying in everyday life. Journal of Personality and Social Psychology, 70(5), 979-995. doi: 10.1037/0022-3514.70.5.979.

Ehrlich, T., \& Fu, E. (2013). Cheating in school and colleges: What to do about it. Retrieved from https://www.forbes.com/sites/ehrlichfu/2013/08/22/cheating-in-schoolsand-colleges/\#43fa464837aa.

Hair, J. F., Black, W. C., Babin, B. J., \& Anderson, R. E. (2010). Multivariate data analysis. Prentice Hall.

Hidayati, K., Budiyono, \& Sugiman. (2018). Development and validation of student's responsibility scale on mathematics learning using subject scaling model. International Journal of Instruction, 11(4), 499-512. doi: 10.12973/iji.2018.11431a.

Kemendiknas. (2010). Pengembangan pendidikan dan karakter bangsa [National education and character development]. Jakarta: Pusat Kurikulum.

Klieger, Aviva, \& Sherman, G. (2015). Physics textbooks: Do they promote or inhibit students' creative thinking. Physics Education, 50(3), 305-309. doi: 10.1088/00319120/50/3/305.

Komalasari, K. (2012). The living values-based contextual learning to develop the students' character. Journal of Social Sciences, 8(2), 246-251. doi : $10.3844 /$ jssp.2012.246.251.

Komalasari, K., \& Saripudin, D. (2018). The influence of living values education-based civic education textbook on student's character formation. International Journal of Instruction, 11(1), 395-410. doi: 10.12973/iji.2018.11127a.

Komalasari, K., Saripudin, D., \& Masyitoh, I. S. (2014). Living values education model in learning and extracurricular activities to construct the students' character. Journal of Education and Practice, 5(7), 166-174.

Krathwohl, D. R., Bloom, B. S., \& Masia, B. B. (1964). Taxonomy of educational objectives: Handbook II: Affective Domain. New York: David Mc Kay.

LaForgia, J. (1988). The affective domain related to science education and its evaluation. Science Education, 72, 407-421. doi: 10.1002/sce.3730720402.

Lickona, T. (2013). Pendidikan karakter: Panduan lengkap mendidik siswa menjadi pintar dan baik [Character education: A complete guide to educating students to be smart and good]. Bandung: Nusa Media.

Mardapi, D. (2008). Teknik penyusunan tes dan nontes [Test and non-test preparation techniques]. Yogyakarta: Mitra Cendekia Press.

Mardapi, D. (2017). Pengukuran, penilaian dan evaluasi pendidikan [Educational measurement, assessment and evaluation]. Yogyakarta: Parama Publishing. 
Mazar, N., Amir, O., \& Ariely, D. (2008). The dishonesty of honest people: A theory of self-concept maintenance. Journal of Marketing Research, 45(6), 633-644. doi: 10.1509/jmkr.45.6.633.

Moten, A. R. (2014). Academic dishonesty and misconduct: Curbing plagiarism in the Muslim world. Intellectual Discourse, 22(2), 167-189.

Muhasim. (2017). Budaya kejujuran dalam menghadapi perubahan zaman: studi fenomenologi masyarakat islam modern [Culture of honesty in facing the changes of the age: phenomenology study of modern Islamic society]. Palapa: Jurnal Studi Keislaman dan Ilmu Pendidikan, 5(1), 74-195.

Novodvorsky, I. (1993). Development of an instrument to assess attitudes toward science. Retrieved from https://repository.arizona.edu/bitstream/handle/10150/186455/azu_td_9410657_sip1_m. pdf? sequence $=1$.

Ogunleye, B. O., \& Babajide, V. F. T. (2011). Generative instructional strategy enhances senior secondary school students' achievement in physics. European Journal of Educational Studies 3(3), 453-463. doi:10.18767/ejes.50757.

Retnawati, H. (2017). Validitas, reliabilitas \& karakteristik butir [Validity, reliability \& characteristics of item]. Yogyakarta: Parama Publishing.

Robinson, J. P., Shaver, P. E., \& Wrightsman, L. S. (1991). Criteria for scale selection and evaluation: in measures of personality and social psychological attitudes. San Diego, CA: Academics Press.

Scheider, W. (1980). 27 Commandments for physics teachers. The Physics Teacher, 18 (1), 32. doi: 10.1119/1.2340404.

Shalvi, S., Eldar, O., \& Meyer, Y. B. (2012). Honesty requires time (and lack of justifications). Psychological Science, 23(10), 1264-1270. doi: $10.1177 / 0956797612443835$.

Tillman, D. (2004). Living values activities for young adults. Jakarta: Grasindo.

Wening, S. (2012). Pembentukan karakter bangsa melalui pendidikan nilai [Formation of nation character through value education]. Jurnal Pendidikan Karakter, II(I), 55-65.

Zuchdi, D., Kuntoro, S. A., \& Prasetyo, Z. K. (2012). Pendidikan karakter: Konsep dasar dan implementasi di perguruan tinggi [Character building: Basic concepts and implementation in higher education] Yogyakarta: UNY Press.

Zuchdi, D., Prasetya, Z. K., \& Masruri, M. S. (2013). Model pendidikan karakter terintegrasi dalam pembelajaran dan pengembangan kultur sekolah [Integrated character education model in school culture learning and development]. Yogyakarta: Multi Presindo. 